Article

\title{
Impact of Government Policies and Corporate Land Grabs on Indigenous People's Access to Common Lands and Livelihood Resilience in Northeast Cambodia
}

\author{
Sochanny Hak ${ }^{1}{ }^{\circledR}$, John McAndrew ${ }^{2}$ and Andreas Neef ${ }^{1, *}$ \\ 1 Development Studies, School of Social Sciences, Faculty of Arts, The University of Auckland, 10 Symonds \\ Street, Auckland 1142, New Zealand; hsochanny@gmail.com \\ 2 Research Consultant, 892 Sheridan Street, Upland, CA 91786, USA; john.mcandrewp@gmail.com \\ * Correspondence: a.neef@auckland.ac.nz; Tel.: +64-9-923-3846
}

Received: 7 September 2018; Accepted: 17 October 2018; Published: 19 October 2018

\begin{abstract}
Cambodia has become a principal target of transnational (and domestic) land grabs over the past decade, mostly in the form of economic land concessions (ELCs). The northeastern part of the country-where the majority of Cambodia's indigenous people reside-is a particular hotspot. In this article, we discuss three policy mechanisms that the Cambodian government has employed to extend and legitimize land exclusions in the name of national economic development through the example of two indigenous villages in Srae Preah Commune, Mondulkiri Province. First, we show how the allocation of two ELCs has deprived indigenous communities of their communally managed land. Second, we examine how communal land titling processes have failed to provide indigenous villagers with effective legal mechanisms to counteract ELCs and land encroachment by internal migrants. Third, we elucidate how the promotion of cash crop production contributed to livelihood and land use transitions from a reliance on forest resources in 2003 to a dependence on cash crops in 2012 to a struggle to remain resilient amid a slump in crop prices in 2018. We conclude that the combination of these policies has undermined communal ownership and livelihood resilience under a situation of limited exit strategies.
\end{abstract}

Keywords: land grabbing; resilience; commons; land concessions; communal land titling; Southeast Asia

\section{Introduction}

Large-scale land acquisitions and leases for agro-industrial, mining, and tourism projects have affected hundreds of thousands of smallholder farmers and communal landholders in Southeast Asia, with indigenous people and ethnic minority groups most at risk (Borras \& Franco 2011 [1]; Kugelman \& Levenstein 2012 [2]; Pearce 2012 [3]; Zoomer \& Kaag 2014 [4]; Neef \& Singer 2015 [5]). Cambodia is arguably a major hotspot of transnational and domestic land grabs, which occur mostly in the form of Economic Land Concessions (ELCs) and occupy a total area of more than two million hectares, with up to 800,000 people affected by land conflicts, dispossession, and forced displacement (Neef et al., 2013 [6]; ADHOC 2014 [7]; Oldenburg \& Neef 2014 [8]). The massive scale of land grabs and the violence surrounding their implementation have been met with various forms of resistance by the rural population. These have ranged from spontaneous protests, counter-violence, and petitions to more sophisticated forms of NGO-led advocacy resistance and the use of transnational networks (McLinden Nuijen et al., 2014 [9]; Neef \& Touch 2016 [10]; Young 2016 [11]; Verkoren \& Ngin 2017 [12]; Lamb et al., 2017 [13]; Schoenberger 2017 [14]).

As a post-colonial and post-conflict country, Cambodia has a particularly chequered land legislation history. During the Khmer Rouge Regime from 1975 to 1979, private land ownership 
was abolished, and all cadastral documents were destroyed (Un \& So 2011 [15]). The long period of civil conflict that followed was marked by unregulated movements of people, land possession by occupation, and state-sanctioned allocation of large-scale forest concessions under the 1992 Land Law (Oldenburg \& Neef 2014 [8]). With international financial and legal assistance, a new Land Law was enacted in 2001, which introduced new property rights categories, including 'state public land', 'state private land', 'economic land concession (ELC)', and 'communal land title (CLT)'. The latter category was supposed to formally acknowledge the communal land rights held by the country's 24 distinct groups of indigenous (i.e., non-Khmer and non-migrant) people, primarily inhabiting the northeastern part of the country. Yet their territories largely overlapped with 'state public land', most of which the Cambodian government has subsequently reassigned as 'state private land' and then allocated to foreign and domestic investors in the form of ELCs. Meanwhile, communal land titling - a protracted process involving several ministries-has benefitted no more than 20 out of over 500 indigenous village communities nation-wide to date (Milne 2013 [16]; ODC 2018 [17]).

Research has shown that the Cambodian government has used its land policies and regulations to legitimize land exclusions and commons enclosures under the name of national and economic development, often in collusion with bilateral donors and multilateral financial institutions (Neef et al., 2013 [6]; Beban et al., 2017 [18]). Neef (2016) [19] argues that land grabs and dispossessions in Cambodia occur by 'government design' rather than by government oversight. In this article, we will look at how ostensibly distinct government policies have actually worked together to deprive indigenous communities in northeastern Cambodia of their communally managed natural resources, thereby making them reliant on volatile cash crop markets and precarious wage work. More specifically, we look at three ways through which the government has pursued its controversial policies and regulations, namely (1) the indiscriminate allocation of ELCs in indigenous territories and protected areas, (2) the sluggish and incomplete registration of CLTs as a policy for indigenous land reform, and (3) agricultural development through promotion of cash crop production.

This article discusses first how two ELC companies in the villages of Srae Ampil and Pukong in Srae Preah Commune, Mondulkiri Province, affected communally managed land. Second, we examine how the government's 2001 Land Law and policies to promote and protect communal land titles have been rendered ineffectual by the lack of political will and the countervailing forces of other government priorities. Third, the article will demonstrate how the government supported policy to encourage cash crop production of cassava and cashew led to livelihood and land use transitions from a reliance on natural resources in 2003 to a reliance on cash crops in 2012 to a struggle to remain resilient amid slumping cash crop prices in 2018.

Our study is the first one that examines the impact of land grabbing on indigenous people in Cambodia over an extended time period of several years, which allows an in-depth analysis of long-term livelihood transitions and changes in community and household resilience. Our mixed-methods approach combines quantitative and qualitative data to allow triangulation of our findings.

\section{Background}

Mondulkiri Province in northeast Cambodia is largely inhabited by the Bunong indigenous people. For centuries they have effectively used the natural resources of their upland forest environment. Since the 1990s, the opening up of the Cambodian economy has had far reaching consequences for the province. Forest concessions and illegal logging, economic land concessions (ELCs), corporate mining concessions, the unregulated hunting of wildlife, and rapid in-migration have diminished the rich natural resources of the province. As of September 2015, 33 ELCs were approved covering 211,317 hectares or nearly 15 percent of the provincial arable land for the cultivation of rubber, cassava, and plantation trees (ODC [20]). As natural resources become more circumscribed, indigenous people have been forced to make adaptations to maintain their livelihoods (McAndrew \& Oeur 2009 [21]). 
Rapid population growth has exacerbated the exploitation of natural resources. Mondulkiri's population more than doubled from 32,407 in 1998 to 72,680 in 2013 (NIS, 2013 [22]), due mainly to Khmer in-migration. Notably, the share of the indigenous population in Mondulkiri Province declined from 71 percent in 1998 to 39 percent in 2013 (Asian Development Bank 2000 [23]; Backstrom et al., 2007 [24]; NIS 2009 [25]; NIS-IP Survey 2013 [26]).

The establishment of ELCs and in-migration are closely linked. Net out-migrations occur mainly from the central areas of Cambodia where population densities are high and agricultural land is scarce (Chheang \& Dulioust 2012 [27]). Government policy encourages displaced and landless populations to resettle in peripheral provinces such as Mondulkiri and promotes ELCs in these areas as opportunities to generate revenue and create jobs locally (ibid). Landless migrant farmers are often contracted upon arrival by agricultural companies to clear land. Many then go on to encroach upon open and degraded forest areas and ostensibly 'unused' or 'non-occupied' land near the concessions. These are inevitably located within indigenous domains. Conflicts often arise between the in-migrants and the concession holders over boundary intrusions, but also between the in-migrants and indigenous people over encroachment into ancestral territories (Chheng \& Dulioust 2012 [27]).

Substantial investments in ELCs in northeast Cambodia have taken place in parallel with the government-supported conversion of smallholder subsistence farming into crop production for the market. Smallholder cultivation of rubber, cashew, and cassava has in turn precipitated a move away from swidden farming to the production of crops on permanent farms (Fox et al., 2008 [28]). In Mondulkiri, cassava production increased dramatically from 546 tons in 2001 to 89,993 tons in 2007, and to 157,505 in 2013. Likewise, the harvested area of cassava in the province rose from 52 hectares in 2001 to 5806 hectares in 2007 and to 10,271 hectares in 2013 (MAFF, 2008 [29]; MAFF 2013 [30]). This sharp increase reflected a change in cassava cultivation from a food crop to an industrial crop with multiple uses such as animal feed and bioethanol. The high export demand for cassava resulted in rising market prices for the crop locally, albeit with some volatility in recent years.

As Bunong indigenous villagers struggle to adapt to the rapid depletion of their natural resource base, progressive legislation enacted in Cambodia since 2000 has provided a legal framework for preventing further decline. The Forestry Law of 2002 recognizes and guarantees the traditional user rights of local communities to collect forest by-products. The Land Law of 2001 enables indigenous communities to gain communal titles to their traditional lands and protects the rights of indigenous communities, formed as legal entities, to use and manage these lands, even before their full ownership rights have been recognized through a communal title. This renders the sale of indigenous land outside the community illegal. However, amid increasing rates of indigenous land alienation, the government has lacked the political will to implement communal land titling (Analyzing Development Issues 2010 [31]). As of 2018, 20 indigenous communities—of which nine are located in Mondukiri Province-had received communal land title certificates (ODC 2018 [17]). In July 2012 the government halted all communal land titling processes under the so-called Order 01. The Order intended to expedite the issuance of private land titles, and thousands of student volunteers were recruited to demarcate lands that had been in conflict with ELCs. This not only formalized prior alienation and fragmentation, it rendered communal and individual titles mutually exclusive and thereby accelerated land commodification (Milne 2013 [16]). Order 01 has been referred to as the 'leopard skin' policy, under which individually owned agricultural plots-like the dots in a leopard skin-are located in a wide expanse of economic land concessions and state public land (Milne 2013 [16]; Oldenburg \& Neef 2014 [8]).

\section{Methods}

This article draws on a mixed-method approach comprising panel data from household questionnaire surveys, in-depth interviews, and participant observation. Household livelihood surveys were conducted in 2003, 2012, and 2018. Based on random samples of 25 percent of the respective population, these surveys were conducted in all six villages of Srae Preah Commune. This commune 
was chosen because of its unique location between two wildlife sanctuaries and the prevalence of two major economic land concessions. Srae Preah Commune comprises five villages, Srae Preah, Pucha, Ochra, Pukong and Gati (Figure 1). Administratively, Srae Ampil village is located in Srae K'tum Commune. However, in 2002 local officials maintained that Srae Ampil village of contiguous Srae K'tum Commune was about to be incorporated into Srae Preah Commune, hence Srae Ampil was included in the original 2003 study. While the transfer never materialized, the researchers in successive 2012 and 2018 studies continued to consider Srae Ampil village as a part of Srae Preah Commune for comparative purposes. The authors of this article likewise continue to do so. At the time of the original survey in 2003 an all-purpose road was being built to the capital town of Sen Monorum which was seen to precipitate social change in Srae Preah Commune.

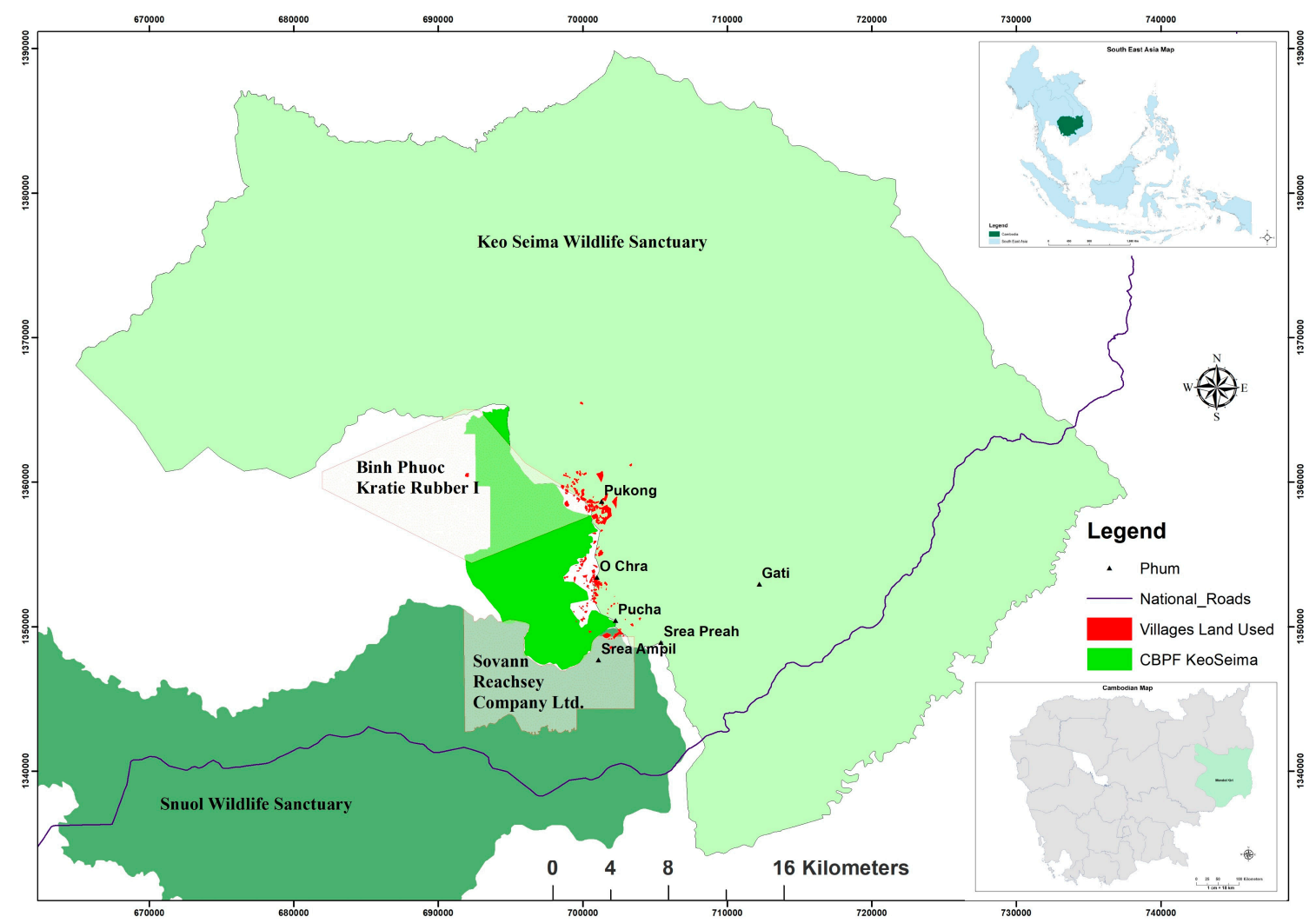

Figure 1. Land use demarcations in Srae Preah Commune. Source: Wildlife Conservation Society's (WCS) Village Land Use GIS Map (2018) [32]; ODC: Economic Land Concessions [20].

In 2003, under leadership of the second author, 74 households were interviewed from a total commune population of 316 households; in 2012, 106 households were interviewed from 430 commune households by a team led by the first author while she was working for a local NGO; and in 2018, 170 households were interviewed from 669 commune households under leadership of the first author. She made an initial visit to the six villages before the final survey was conducted in 2018 to obtain household lists from the household record books provided by the village chiefs and inform the local authorities and village elders about the study objectives and fieldwork schedule. Household lists provided by the commune and village chiefs were validated and updated through spot mapping. Both Khmer and indigenous Bunong families were randomly selected from the household lists. Since the survey questionnaire focused on livelihood experiences, all household members aged over 15 years were encouraged to attend the interview. For Bunong respondents, indigenous Bunong research assistants were recruited to ask the survey questions primarily in the Bunong language and record the responses in Khmer. 
The qualitative case studies discussed in this article focus on Srae Ampil and Pukong villages. The first author and her research assistants sought permission from local authorities, including commune and village leaders before starting the fieldwork. A total of 31 in-depth interviews with 16 men and 15 women were conducted. The criteria for the selection of respondents for the in-depth interview were (1) earning their living predominantly from farming, (2) having lived in the village more than one year prior to the in-depth interview, and (3) being knowledgeable about previous land disputes with ELC companies or forest encroachment. Participation was based on informed and voluntary consent. Among the 31 in-depth interview respondents, nine had participated in the household livelihoods survey 2018 and another nine respondents had been involved in both the 2012 and 2018 studies. The in-depth interviews were conducted by the first author in Khmer. Bunong research assistants helped to facilitate translation from the Bunong language to Khmer when needed. Participant observation was employed to understand perspectives of the respondents in relationship to their land ownership title and agriculture practice. The first author and her research assistants spent about two weeks in each of the two villages to build trust with research participants and village elders. To minimize the risk of cultural misrepresentation and misunderstanding, frequent consultations with Bunong research assistants and village elders were held during the stay in the villages.

Data from the household survey were analyzed by using descriptive statistics. The data were disaggregated by gender and type of household wealth (better-off, above poor, poor, and very poor households) and cross-tabulated among relevant variables to examine their associations. Data from different sources, and primary and secondary data, were triangulated where appropriate.

The in-depth interviews were audio-recorded, transcribed, and translated into English by the first author. Responses were classified by themes emerging from the transcripts. The analysis of the in-depth interviews was based on themes developed in the field and emerging from the transcripts.

\section{Results}

This section is divided into three parts. The first part examines how the ELCs in the villages of Srae Ampil and Pukong encroached upon common lands of indigenous people and how the conflict resolution processes unfolded. These are the two villages in the commune whose common lands have been most affected by the establishment of ELCs. The second part scrutinizes the impacts of the 2001 Land Law and policies that aim to ensure tenure security of indigenous communities through the Communal Land Titling scheme. The final part discusses livelihood transitions and land use change as a consequence of government policies that encourage crash crop production. This last part will demonstrate how the livelihoods in Srae Preah Commune have been transformed from a natural resource reliance (2003) to a dependence on cash crops in 2012 and the subsequent struggle of communities and households to remain resilient against the backdrop of the cash crop price decline in 2018. The first and second parts draw on the findings from the in-depth interviews and participant observation conducted in 2012 and 2018, while the third part compares the results from the household livelihoods surveys organized in 2003, 2012 and 2018.

\subsection{The Pursuit of Economic Land Concessions}

The two case studies of Srae Ampil and Pukong villages affected by two distinct ELCs are based primarily on the in-depth interviews conducted in 2012 and 2018. The case studies examine the corporate land incursion on common land through the government's development strategy to attract foreign and local investment on its natural forest. This part also illuminates processes and strategies of conflict resolution. Newspaper articles and NGO reports were examined to verify the events and dates described by the respondents during the in-depth interview. 


\subsubsection{The Case of Sovann Reachsey Company Limited in Srae Ampil village}

In December 2010, Vietnam-based Sovann Reachsey Company Limited was awarded a 6525 hectare concession for 90 years to develop an agro-industrial plantation for rubber and other crops. The land is located within Snuol Wildlife Sanctuary which borders Snuol District of Kratie Province and Keo Seima District of Mondulkiri Province. The company's initial operation affected approximately 500 hectares of forestland inside Srae Ampil village (Table 1).

Table 1. Summary of events related to communal land titles and ELCs in Srae Ampil and Pukong villages.

\begin{tabular}{|c|c|c|}
\hline Theme & Srae Ampil & Pukong \\
\hline $\begin{array}{l}\text { Indigenous } \\
\text { Community }\end{array}$ & $\begin{array}{l}\text { 2009: NGO (DPA) supported the village } \\
\text { to establish itself as a community for } \\
\text { CLT registration. }\end{array}$ & $\begin{array}{l}\text { 2009: NGO (DPA) supported the village } \\
\text { to establish itself as a community for CLT } \\
\text { registration. }\end{array}$ \\
\hline ELC & $\begin{array}{l}\text { 2010: Sovann Reachsey Company was } \\
\text { awarded an ELC on } 6525 \text { ha inside } \\
\text { Snuol Wildlife Sanctuary which affected } \\
\text { about } 500 \text { ha of forestland in Srae } \\
\text { Ampil. }\end{array}$ & $\begin{array}{l}\text { 2011: Binh Phuoc Kratie Rubber I } \\
\text { Company was awarded an ELC on } 8926 \\
\text { ha inside Seima Biodiversity } \\
\text { Conservation Forest which affected about } \\
2000 \text { ha of forestland in Pukong. }\end{array}$ \\
\hline Illegal Logging & $\begin{array}{l}\text { 2011: Illegal logging was perpetrated by } \\
\text { individual loggers and loggers } \\
\text { associated with the ELC company. }\end{array}$ & $\begin{array}{l}\text { 2013-2014: Illegal logging was } \\
\text { perpetrated by individual loggers and } \\
\text { loggers associated with the ELC company. }\end{array}$ \\
\hline Forest Patrol & $\begin{array}{l}\text { 2011-2014: A forest patrol was } \\
\text { organized }\end{array}$ & 2013-2017: A forest patrol was organized. \\
\hline Protest & $\begin{array}{l}\text { 2011: At least two protests were } \\
\text { organized by Srae Ampil villagers } \\
\text { against the company's operation. }\end{array}$ & No protest of villagers. \\
\hline Media coverage & $\begin{array}{l}\text { 2011: Villagers contacted a local } \\
\text { newspaper and NGOs working in the } \\
\text { area. }\end{array}$ & $\begin{array}{l}\text { 2013: A six-member NGO committee was } \\
\text { formed to support the villagers and } \\
\text { investigate the conflict. }\end{array}$ \\
\hline Forest encroachment & $\mathrm{N} / \mathrm{A}$ & $\begin{array}{l}\text { 2014: Forest encroachment took place by } \\
\text { Khmer and Cham villagers and powerful } \\
\text { government officials. }\end{array}$ \\
\hline $\begin{array}{l}\text { Conflict Resolution } \\
\text { with ELC companies }\end{array}$ & $\begin{array}{l}\text { 2015: Final conflict resolution reached: } \\
\text { the company compensated villagers in } \\
\text { cash for the land which had already } \\
\text { been cleared and cut. A total } 250 \text { ha } \\
\text { from the concession plan was } \\
\text { transferred to the villagers. }\end{array}$ & $\begin{array}{l}\text { 2014: Final conflict resolution reached: the } \\
\text { company compensated the resin trees } \\
\text { owners in cash for the resin tress that } \\
\text { were cut by the company. }\end{array}$ \\
\hline
\end{tabular}

Srae Ampil village, established in the late 1980s, is primarily inhabited by Bunong people, followed by Stieng and Khmer. The villagers have traditionally relied mainly on non-timber forest products (NTFPs), including liquid and gum resin, and paddy rice cultivation as their main livelihood sources. Since the village is located in a protected area bordering Srae Preah Commune and Snuol Wildlife Sanctuary, no formal ownership to their land is acknowledged by the law. However, because this village is predominantly composed of indigenous people, namely, Bunong and Stieng, according to the Land Law 2001, it is eligible to apply for a CLT that would allow them to occupy their land resources collectively. In 2010, with the support from a local NGO (Development and Partnership in Action-DPA), the village was officially recognized by the Ministry of Rural Development (MRD) as an indigenous community. This formal recognition constituted Stage 1 of the CLT registration. ${ }^{1}$

1 The process of communal land titling is described in detail in Section 4.2 below. 
This was followed by the establishment of a community management committee, in which the members of the community elected a leader.

After receiving the ELC license, the Sovann Reachsey Company did not inform the villagers about their investment plan or the land area to be affected. The company sub-contracted a local company to clear land and hired loggers to cut timber inside its designated area. However, the villagers maintained that the logging occurred inside the forestland of the community. By 2012, more than 2000 resin trees had been cut. In response, the management committee of the community formed groups to patrol their forest.

Further to patrols, the villagers organized protests and contacted media outlets and NGOs for help. Forest patrols were not effective in stopping illegal logging, especially when loggers were associated with the company. Frustrated by this failure, the villagers organized two major protests. In the first protest held in May 2011, the villagers confronted the company's workers while they were clearing the land in the community forest. The company asked the military police to intervene. The police came and arrested three villagers and accused them of damaging the company's equipment. In the second protest that took place in October 2011, village households gathered at the contested area and stopped the company's workers from cutting logs and clearing the land. The villagers demanded that the district authorities resolve the conflict by demarcating the land clearly and by putting a stop to illegal logging.

During the protests, villagers contacted NGO staff and asked them to witness the confrontation. Radio and newspaper outlets also came and reported on the protests. An American radio network (Radio Free Asia-RFA) regularly broadcasted the news. The community leader's strategy was to publicize the protests and attract the authorities' attention. Patrol teams would take pictures of illegal logging operations and send them to the media to broadcast. In an interview in 2012, a male community leader stated: "We called ... [the district governor and commune leader] but they did not respond. When the RFA interviewed some of us, the district governor and commune chief came to the village and pleaded with us not to report to the RFA. Before we contacted RFA, we had asked the authorities to intervene two or three times. But there was no action. If we had not asked RFA to broadcast the news about the conflict, the local authorities would not have intervened." (San, male, community leader, Srae Ampil, 2012). ${ }^{2}$

In response to the strong local resistance movement, the company agreed to suspend its land clearing operation in 2012. However, the logging still continued. Moreover, land clearing inside the community forest of 500 hectares was started in 2012 by both local people and military officials. Local people reported that environmental officials did not allow them to clear the land as it was a protected area. Military police officials raided the area and forced them to leave. In the meantime, however, several military officials cleared the land inside the conflict area for their own benefit.

A conflict resolution process was started with the company in 2014. The elected community leader and members of the management committee reported that they were contacted by the company representatives to seek informal negotiation. The district governor also contacted the community representatives to discuss negotiation strategies. In 2015, the final agreement was reached when the company agreed to demarcate the land boundaries and share half of the contentious land area with the community. The company also promised to pay for the loss of the land amounting to 250 hectares, provide employment opportunities to the villagers, and construct a village road. Moreover, the company agreed to offer financial support for a spiritual ceremony as requested by the village elders. The remaining 50 percent of the land amounting to 250 hectares was distributed to the village households. In 2017, the final compensation for the lost land was paid and the land distribution to the village households was completed. The company then built a canal that surrounded its land boundaries. 
Before the final conflict resolution was reached, solidarity and cooperation among the community members were strong. The community leader observed that the committee members frequently convened meetings with the villagers to share information about the negotiation results and consulted with them about strategies. This collegial relationship broke down after a disagreement on the final solution. A total of 10 of the 75 village households refused to accept compensation from the company and continued the protest to reclaim their land. Meanwhile, another six households claimed that their neighbors had occupied plots that were supposed to have been delivered to them.

Despite its promise to provide employment opportunities, the company ended up employing only a small number of villagers. Five of the committee members were hired as full-time security guards and 10 other villagers were hired as seasonal workers on banana and rubber plantations. The committee members hired as guards resigned after working for the company for about two years. They complained that the company frequently delayed payment of their salaries, paid them only once every two or three months, and added extra working hours without providing overtime pay.

\subsubsection{The Case of Binh Phuoc Kratie Rubber 1 Company Limited in Pukong Village}

Binh Phuoc Kratie Rubber 1 Company, a subsidiary of state-owned Vietnam Rubber Group (VRG), was granted an 8926-hectare ELC in 2011 for rubber plantations. ${ }^{3}$ The ELC land, located inside Seima Protected Area and Biodiversity Conservation (SPA), ${ }^{4}$ affected Srae Preah and Srae Chhouk Communes in Keo Seima District. In Srae Preah Commune, about 2000 hectares of forestland in Pukong village were affected (Table 1).

Pukong village, established in 1940, is predominantly inhabited by Bunong with a sizeable minority of Khmer migrants who moved into the village in the late 1990s. The villagers have depended on the collection of NTFPs, including liquid resin, swidden farming, and paddy rice cultivation as their main sources of livelihoods. Since the village is inside the core zone of SPA, ${ }^{5}$ in 2006 an international NGO, Wildlife Conservation Society (WCS), assisted the Forest Administration (FA) to create a Community-Based Production Forest (CBPF) that covers the village and two other villages of Srae Preah Commune (Figure 1). A management committee of the CBPF was created and a forest extraction plan was developed. However, since the CBPF is inside the protected area, the Forestry Law of 2002 prohibits any extraction of forest resources. Concurrently, in 2009 DPA supported the villagers to establish itself an indigenous community so that it could apply for a CLT. By 2012, the village reached Stage 2 of the community land titling process. Yet, by early 2018, the village was still struggling to reach the final stage.

As in the Srae Ampil case, the company did not conduct any consultation meetings with the villagers upon receiving their license. The villagers said the ELC sub-contracted a local company, which was well-known for engaging in the logging trade and presided over by a powerful tycoon, to cut trees inside its land area. The local company, however, expanded its logging into the CBPF and transported the logs to the ELC's designated area to make them legal for export (NGO Report, $2015[35])$.

Since 2012 with support from WCS the villagers have conducted patrols to protect their CBPF. The patrol teams often encountered logging workers and confiscated their equipment. Consequently, they faced death threats by armed forces recruited by the sub-contracted company to guard its logging

3 The company land size was reduced to 5100 hectares in 2012 by an inter-ministerial committee led by the Minister of Environment.

4 The Seima Protected Area (SPA) and Biodiversity Conservation which was under the Forestry Administration (FA) of the Ministry of Agriculture, Forestry and Fishery (MAFF) was changed to Keo Seima Wildlife Sanctuary (KSWS) under the management of the Ministry of Environment (MoE) in 2016.

5 For management purposes, the protected area was divided into four zones for sustainable management, namely (1) a core zone which is a high-value forest area where access to forest resources or swidden cultivation is restricted, (2) a conservation zone, (3) a sustainable use zone, and (4) a community zone (ODC Website [33], WCS REDD+ Program Monitoring and Evaluation Report, 2018 [34]). 
operation. In response, the village representatives lodged a complaint against the illegal logging and the destruction of resin trees in the CBPF to the provincial governor. No action was taken by the provincial governor but a few days later, the district governor issued a letter to the company, instructing them to confine the logging to the ELC's land area. Nevertheless, the logging activities were further expanded between 2013 and 2014. Further to forest patrols, the villagers contacted some news agencies to publicize the illegal logging and demanded an intervention from the government.

In 2013, a group of six local NGOs formed a special committee to investigate the complaint and provide support to the villagers. A series of activities were organized and facilitated by the committee, including consultative meetings between company staff and the villagers, and press conferences. Meanwhile, the villagers continued to conduct patrols. However, because of the involvement of military personnel, the community members said they did not have the motivation and capacity to patrol without the support from WCS or officials from the Provincial Department of Environment (PDE). The forest patrols, albeit done regularly, yielded limited success.

Unlike the Srae Ampil villagers, the Pukong villagers did not organize any protest. In 2014, the ELC built a canal that surrounded its land area. They did this by carving out about 500 hectares of land designated by the Forest Administration as a dense forest and which included the villagers' spiritual ground. Despite the boundary demarcation, illegal logging and land encroachment inside the CBPF continued at an ever-larger scale. In the same year, the 500-hectare land area returned by the company was occupied by two powerful military officials. Additionally, about one hundred hectares of the CBPF were cleared by more than $100 \mathrm{Khmer}$ and Cham households who were former ELC workers.

In 2017, in response to the continuous land encroachment inside the CBPF and the ineffectual forest patrols, a group of villagers cleared the land along the border of the CBPF next to the ELC. However, they were expelled from the area by PDE officials who, on the basis of the Forestry Law of 2002, declared that land clearing or occupying land inside a protected area was not allowed. Frustrated with the inability to expand their farmland and the failure to stop land encroachment, some villagers continued to work on their existing farms although with a shift to cash crop cultivation of cashew nut and cassava. Others took the risk to secretly clear land inside the protected area. In a 2018 interview, an NGO staff member maintained that between the years 2013 and 2017 the deforestation rate in the CBPF was 44 percent. This meant that during this time over 5000 hectares of the CBPF had been cleared and occupied.

\subsection{Promulgation of Communal Land Titling Program and Impacts on Indigenous Communities}

This section discusses the government's Land Law of 2001 and the challenges that indigenous communities face to complete the final stage of the CLT process. The discussion draws mainly on in-depth interviews from 2012 and 2018 and from previous studies on the subject matter.

\subsubsection{The Communal Land Titling Program under the 2001 Land Law}

The Land Law of 2001 adopted by the Royal Government of Cambodia includes a provision aimed at giving indigenous peoples' tenure security through Communal Land Titles (CLTs). The recognition of customary land use of indigenous people stated in the law has been regarded as a significant step forward to promote the respect of indigenous people rights in Cambodia. It entitles them to collective ownership on their traditional lands including residential land, agricultural land, and the reserve land for swidden farming (Backstrom et al., 2007 [24]). Moreover, Article 23 of the law provides a precise legal definition of indigenous communities as legal entities for communal land ownership (Brown et al., 2005 [36]). However, the law alone was not sufficient to grant CLTs until the government issued a sub-decree on the Procedure of Land Registration of Land of Indigenous Communities in 2009 (RGD, 2009 [37]). It provides a clear procedure and guidelines starting from the registering of indigenous communities to the issuance of CLT certificates. The process involves three stages and needs the recognition and approval by three different ministries. First, an interested village must establish itself as an indigenous community and be recognized by Ministry of Rural 
Development (MRD). Second, the indigenous community must develop community bylaws and a management committee, and then register itself as a legal entity with the Ministry of Interior (MoI). The third and final stage involves registering the already measured land with the Ministry of Land Management, Urban Planning and Construction (MLMUPC) in which CLT certificates will be issued (ODC Website [38]). All three stages involve various inter-ministerial committees and take several years to complete.

Srae Ampil and Pukong villages have been engaged in the process of acquiring CLTs since 2009 with the support from NGOs. As of May 2018, Srae Ampil village had just completed the measurement of communal land, while Pukong village had completed the measurement in 2017. However, both villages have not yet received CLT certificates. ${ }^{6}$ The process of CLT land registration in the two villages has been delayed because of land conflicts with ELCs. In Srae Ampil village, the land measurement was conducted for a second time in April 2018 after the final conflict negotiation with the Sovann Reachsey Company was completed. The process of land registration has been further complicated by the fact that the requested CLT area is located within a protected area. The government needs to issue a sub-decree to convert the requested land area from the status of 'state public land' into 'state private land'. Only then it can be legally awarded (cf. Baird 2013 [39]). The land areas of both Srae Ampil and Pukong villages are located inside the SPA and therefore it will take a long time to complete the final procedures. With the process of CLT land registration delayed, opportunities remain for further land encroachment within the communal land area and outside the communal land area (Ngin \& Diepart 2016 [40]).

Of note, large land areas outside of the CLTs are under the legal status of 'state public land'. In Srae Ampil village, 750 hectares are registered as forestland while in Pukong village more than 10,000 hectares are designated as forestland under the status of 'state public land' (Table 2). This raises the question of whether land under the category of 'state public land' will be granted to the future use of indigenous peoples or reserved as common land for environmental protection (cf. Baird 2013 [39]).

Table 2. Type of Village Land Use, As of May 2018.

\begin{tabular}{ccc}
\hline Type of Land Use & Srae Ampil & Pukong \\
\hline Household Population (hh) & 115 & 89 \\
Land under CLT (ha) of which & 523 & 392 \\
Residential land & 46 & 24 \\
Farmland & 214 & 122 \\
Paddy rice fields & 115 & 65 \\
Reserve land & 134 & 162 \\
Spirit forest & 7 & 8 \\
Burial ground & 7 & 11 \\
Forestland not under CLT (ha) & 750 & 17,328 \\
Total arable village land size (ha) & 1273 & 17,720 \\
\hline Source: DPA GIS Map of Srae Ampil (2018) [41]; and WCS GIS Map (2018) [32].
\end{tabular}

In Pukong village, nearly 1000 hectares of state public land inside the CBPF have been cleared and occupied by individual land encroachers and powerful elites. In Srae Ampil Commune, a villager expressed his concern that the forestland near the Keo Seima mountain would also be encroached when population in the village increases.

6 In Srae Ampil village, the whole process of communal land titling including the initial establishment of indigenous community has been solely supported by a local NGO, Development and Partnership in Action (DPA). To reach the final stage of land registration (measuring land, issue a community land use mapping, and convening meeting with member of committee) costs approximately USD 4000 (personal communication, 2018). In Pukong, DPA and WCS provide the support. 


\subsubsection{Communities Shifting Perceptions about CLT}

Local people expressed mixed opinions about the potential benefits of CLTs. Some villagers thought that CLTs provided some benefits to their community, while others disagreed. One committee member from Srae Ampil asserted that CLTs both ensured communal land ownership and supported indigenous peoples' ways of life. He maintained that with collective titles, poor households would likewise retain the ability to collect non-timber forest products and would not have to rely solely on permanent farms that required financial investments in crop cultivation. He argued:

"The communal land title is important to us because it allows us to protect our community forest, and maintain our culture, tradition and beliefs. I do not want to lose it ... It is also helps poorer families. Without the community, we cannot protect our community forest, and the poorer families cannot earn from forest resources ... We protect the forest not only for our own benefit, but for the benefit of the poorer families in the village." [Soktha, male committee member, 2018, Srae Ampil]

A management committee member of the indigenous community in Pukong village maintained that once the community received the CLT, it would be able to stop land encroachments because the boundaries of the community land would be officially recognized by the government's institutions. He stated:

"I still think that we must unite as one community ... If we stay together as one community, our voices and actions will be stronger to stop the forest encroachment. I am still optimistic that sooner or later we can stop the forest encroachment." [Bunna, male committee member, 2018, Pukong]

At the same time many villagers have become increasingly frustrated with the prolonged process of CLT land registration. They are unsure whether they will eventually be able to receive the full benefits from the CLT. Given the continued expansion of land encroachment, an acting community leader in Pukong lamented:

"Villagers) are upset about losing forest lands due to forest encroachment. They have been waiting for the CLT certificate for a very long time. Some of them do not understand the meaning of state public land and state private land. The villagers thought that all the land area in Pukong village belongs to Pukong villagers... In reality, the land belongs to the state and is under the management of the state, not under the community." [Sao, male, acting community leader, 2018, Pukong village]

Notably, the enthusiasm about continuing the CLT registration process has been significantly dampened since companies and in-migrants have encroached upon and occupied common land. Without opportunities to clear new land for swidden cultivation, the villagers work intensively on their permanent farms, now converted from subsistence cultivation to the production of cash crops (see Section 4.3 on livelihood transition). The capacity to expand farmland and crop cultivation entails capital investment and having private land titles instead of the CLT is viewed by some as a better strategy for securing loans.

As a mother of three and wife of a former community leader in Srae Ampil argued:

"I would rather have a private land title. I cannot use the communal land title certificate to borrow money from the banks [i.e local microfinance institutions]. But, with a private land title ... I can borrow money and use the land as collateral. I can borrow and repay as much as 1 or 2 million riels. I could get this amount immediately with a private land title." [Kyao, female villager, 2018, Srae Ampil]

Over time the perceived benefits of registering for the CLT has changed for several villagers that were interviewed. In 2012, during the initial stages of the CLT registration process, there was strong enthusiasm for CLTs in both villages. People viewed the CLTs as an opportunity to conserve both communal lands and forest lands. For example, a community leader interviewed in 2012 expressed his preference for the communal land titling process in this way: 
"After the community is formed, no villager is allowed to sell land to outsiders. In the village, there is still a large area of unoccupied land, but it will be kept for distribution to community members in the future. Forest areas will be kept as a land reservation for villagers who are landless or for new families." [San, male villager, 2012, Srae Ampil]

However, when this same respondent was interviewed again in 2018, he expressed his strong discontent with the protracted community land titling process. He said that he felt powerless to defend communal natural resources in the village. By that time, the deal had been struck with the company and the remaining part of the communal forest had been equally distributed to the villagers. Furthermore, some villagers had already sold their share of the land to Khmer and Cham in-migrants.

At the same time this respondent maintained that if land had not been distributed to individual villagers, outsiders or powerful military officers would have come in and taken over the land. He lamented:

"I am disappointed that we do not have the power to take action to protect our own resources. Some land areas have been allocated to the community, but powerful people have hired workers to cut down big trees in our community forest, and we could do nothing to stop them from destroying our resources." [San, male villager, 2018, Srae Ampil]

Similarly, Pukong villagers perceived in 2012 that having a CLT would be a good way to secure land ownership for the community. At that time they had not experienced corporate incursions but were nevertheless concerned about land encroachments. As one respondent said at the time:

"Many villagers have concerns about future land encroachments if the collective land title will not be issued to them in the near future." [Sao, male villager, 2012, Pukong]

This perception had changed in 2018 when it became clear to Pukong villagers that they were not able to stop corporate land incursions and forest encroachments that had occurred in their community since 2014.

Interviewed again in 2018 this same respondent stated:

"Forest encroachment is the issue affecting trust and integrity in our village. It contributes to the breaking down of community solidarity. These days I go from house to house to collect thumbprints [attesting to the request for the CLT]. Some villagers tell me that they do not want to provide their thumbprint as they do not have trust in the communal land title." [Sao, male villager, 2018, Pukong village]

In sum, the government policy of prioritizing the allocation of ELCs over the registration of CLTs has led to changes in the communities' perceptions about communal land rights and caused internal divisions regarding the further courses of actions to defend natural resources that were once managed collectively.

\subsection{Government Support for Cash Crop Production and Livelihood Transitions from 2003 to 2012 to 2018}

As outlined in Section 2, the Cambodian government's aggressive promotion of ELCs in Mondulkiri Province took place concurrently with government support for the conversion of smallholder subsistence farming into cash crop production. Both policies served to promote Khmer in-migration. In only six years, from 2012 to 2018, the household population in Srae Preah Commune had increased by 56 percent. This did not include a group of about $170 \mathrm{Khmer}$ households who had taken up residence on communal lands in $\mathrm{O}^{\prime}$ chra village and a group of more than $100 \mathrm{Khmer}$ and Cham households in Pukong village. Both of these groups were not yet officially registered in the village family record books.

Overall, government support for cash crop production in Srae Preah Commune-along with the government's incoherent and controversial land policies-contributed to dramatic livelihood 
transitions and land use changes. This in turn resulted in the dispossession from land and forest resources, a reliance on cash crops, land commodification, land concentration, social differentiation, and economic inequality. In this section we present findings and analysis which support this argument. We draw on the 25 percent random sample household surveys that were conducted in 2003, 2012, and 2018 (see McAndrew et al., 2003 [42], Hak et al., 2015 [43], and Hak et al., 2018 [44]).

In Srae Preah Commune the principal livelihood transition to emerge from 2003 to 2012 was the shift away from the reliance on forest products, hunting, and trapping to the cultivation of cash crops such as cassava and cashew nuts for the market (Table 3). This resulted in more households being involved in upland farming and the expansion of upland areas under cultivation. That noted, in 2012 upland farm sizes varied greatly among cultivators underscoring that households benefited unequally from the cash crop market. On average, the better-off households cultivated much larger upland parcels and had substantially higher earnings from cash crop production than did other income groups. By comparison, the very poor households had the smallest upland farms and the lowest earnings from cash crop production. Similarly, the better-off households cultivated larger wetland areas and had higher earnings from paddy production than did the other groups.

Table 3. Shares of different income sources in total average household income Srae Preah Commune for the years 2003, 2012, and 2018 (in percent).

\begin{tabular}{cccc}
\hline Source of Income & $\mathbf{2 0 0 3}$ & $\mathbf{2 0 1 2}$ & $\mathbf{2 0 1 8}$ \\
\hline Cultivating crops & 24 & 51 & 26 \\
Raising pigs and poultry & 13 & 4 & 11 \\
Collecting forest products and hunting or trapping & 49 & 32 & 26 \\
Fishing & 3 & 2 & 2 \\
Handicrafts and trade & 5 & 3 & 15 \\
Wage work & 6 & 8 & 20 \\
Total & 100 & 100 & 100 \\
\hline
\end{tabular}

Source: McAndrew et al., 2003 [42]; Hak et al., 2015 [43]; Hak et al., 2018 [44].

In 2003 food and other products gathered from the forest-including hunting and trapping-accounted for 49 percent of total household income. This underscored the reliance of Srae Preah households on forest resources for their livelihoods. By contrast, in 2018 food and other products gathered from the forest accounted for only 26 percent of total household income. The diminished contribution of forest resources to household incomes was largely the result of a rapid decline in liquid resin tapping as a major source of household earnings. Remarkably, total household income from the collection of liquid resin plummeted from 28.4 percent in 2003 to only 4.0 percent in 2012. Notably, the very poor households with the smallest upland farms earned more proportionally from gathering forest products in 2012 than did most other income groups.

The opening up of lands for cash crop production and paddy rice cultivation spurred economic growth, but at the cost of exacerbating the threat posed to forested areas and household livelihoods reliant on forest resources. Meanwhile the rapid adoption of cassava as a boom crop raised concerns of its own. Reliance on cassava production made indigenous households more vulnerable to the exigencies of the market economy. Critically, though perhaps less well understood, the pursuit of cassava cultivation had consequences for social differentiation. As noted above, income earned from cassava cultivation was related to upland farm size. Better-off farmers cultivated larger upland areas and earned more from cassava production than did other income groups. In the previous five years, better-off households had likewise augmented their holdings, buying up more upland than other income groups.

The accumulation of land in the hands of better-off households threatened to result in the dispossession of smallholders, potentially to the point of landlessness. While cassava production created opportunities for agricultural labor, very poor households in the commune earned proportionally less from wage work than did most other income groups. Moreover, the very poor 
households, like the other income groups, earned little or nothing from trading and migrant remittances. This revealed that livelihood opportunities and exit options for the very poor households remained limited. Loss of upland farms and access to forest resources would, no doubt, leave them further displaced and marginalized.

In 2012 the prospects for economic development in Srae Preah Commune looked promising. Poverty levels had dropped from 63 percent in 2003 to 43 percent in 2012 as cash crop production of cassava and cashew nut emerged to offset the declining earnings from forest products. ${ }^{7}$ The transformation of swidden agriculture from household subsistence cultivation to the production of cash crops for sale in the market was all but complete. While the 2012 study acknowledged the vulnerability of cash crop cultivators to the volatility of cassava prices, the sharp decline in cassava earnings in 2018 was unforeseen.

From 2012 to 2018 household earnings from cultivating crops dropped from 51 to 26 percent (Table 3). Specifically, cassava earnings dropped from 19.6 percent of total annual household income in 2012 to 9.4 percent in 2018. Again, this sharp decline in earnings from cassava production was completely unexpected. Clearly the rapid household population growth from 2012 to $2018 \mathrm{did}$ not translate into a comparable increase in cassava earnings. The decline in total cassava earnings resulted from a drop in the percentage of sample households cultivating cassava and from a drop in the percentage of overall earnings from cassava production itself. Increasingly, upland farmers in Srae Preah commune were dissuaded from investments in cassava production due, in part, to cassava root damage from excessive rain, to volatile cassava prices, and to higher production costs. As a consequence, the incipient cash crop cassava boom evident in 2012 never fully materialized. Of note, the Gini-coefficient of 0.45 for the sample households in 2018 was much higher than the Gini-coefficient of 0.38 calculated for the sample households in 2012. This indicates that income inequality among Srae Preah households had become more severe.

Overall, the principal livelihood trends taking place in Srae Preah Commune from 2012 to 2018 were a decline in earnings from cassava and wet-rice production, a more widespread and organized involvement in the illegal timber cutting, increased earnings from handicraft and trade, and a greater reliance on wage work. The rapid rise of the household population in the commune from 2012 to 2018 increased pressure on land and forest resources and constrained overall economic growth. Without government enforcement of the provisions of the land titling program, indigenous access to ancestral lands deteriorated noticeably and successful livelihood transitions among indigenous households remained elusive.

\section{Discussion}

Our findings confirm that ELC investment, which converts forestland into agro-industrial plantations, is a form of 'commons grabbing' (Haller 2016 [46]) that has profound impacts on livelihood resilience, particularly among those groups that depend on communally managed forest resources for their subsistence. The ELCs in both Pukong and Srae Ampil adversely affected indigenous people who used to access forest resources as their main source of livelihoods. As a consequence, the villagers' reliance on forest resources has declined, but their dependence on commercial crops has dramatically increased (Hak et al., 2015 [43]). In furtherance, the leopard-skin policy which was developed after the government granting ELCs to strengthen implementation of ELCs and avoid land grabbing by concessionaires has created space for land control by powerful elites and those affiliated to them.

7 Figures for 2003 are based on the poverty line of 1036 riels per capita per day for rural areas set by the Ministry of Planning (MoP) and the United Nations World Food Programme (WFP) (2003). Figures for 2011 are based on World Bank estimates of the poverty line of 4422 riels per capita per day for rural areas (World Bank 2013 [45]). Since the poverty line for rural areas in 2003 by the World Bank was unavailable, the authors refer to the poverty line in 2003 set by the Ministry of Planning (MoP) and the World Food Program (WFP). 
The Pukong villagers were not able to claim back the dense forest and their spiritual ground as it was subsequently processed for land ownership by military police officials.

The two villages took different responses to the land grabbing by concessionaires and adopted different strategies for livelihoods changes. Apparently, the villagers of Srae Ampil took outright resistance against Sovann Reachsey Company in 2012 which resulted in a favorable solution in terms of land restitution. Through their protest and submission of a petition which attracted temporary media attention, the Srae Ampil villagers reached a final conflict resolution with monetary compensation and employment opportunities from the concessionaires. Yet, they lacked an effective mechanism of monitoring the actual implementation of the company's promise and their localized social movement dissolved after they reached a final agreement. In 2018, they have given up their efforts and changed to a tactic of acceptance and accommodation to land grabbing. They have increased the intensity of cash crop cultivation on their permanent farms which in 2016/17 was hit by the cassava price downturn and resulted in loss of profits for the smallholder farmers.

In contrast, Pukong villagers did not show significant resistance against the concessionaire. Instead, they secretly expanded their farmland into protected areas for cash-crop cultivation. Following Scott's (1986) [47] notion of 'infrapolitics', the Pukong farmers took a form of covert resistance to land grabbing. Since they were not able to attract attention from the authorities in dealing with land encroachment, they took the risk of clearing land in protected areas although they knew that it was illegal. Yet their actions yielded limited or no results, and they were left more vulnerable to land grabbing because they had no power to resist encroachment by military officials and internal migrants.

These findings add to the nascent body of literature that suggests that resistance to land grabbing in rural Cambodia takes mostly the form of community-based, localized struggles, which Baird (2017) [48] calls 'contingent contestations'. Indigenous farmers adopt various strategies in response to the loss of their common land, but mainly in an unstructured, unplanned and sporadic manner (Neef \& Touch 2016 [10]). This lack of coordination tends to lead to unanticipated outcomes, even when it involves ostensibly 'successful' land restitution.

On the surface, the tenure reforms that were instigated under the 2001 Land Law seem to have provided new opportunities to indigenous communities to defend their communal natural resources. Yet, in fact, the government's lackluster implementation of the CLT policy-while at the same time aggressively pursuing the allocation of ELC-diminished their common land and spurred land grabbing by local elites and in-migrants. This paradox of the CLT policy reveals the contradiction explained in the theory of evasion (Biddulph 2011 [49]). The CLT policy was originally intended to provide formal resource ownership to indigenous communities so that they can secure their tenure rights and exclude non-indigenous people from encroaching on their ancestral lands. However, the government's forest policy and the leopard-skin policy under Order 01 has converted large portions of their communal land to community-based or state-public land, which has paved the way for encroachment by external forces. As a consequence, land concentration in the indigenous communities has intensified and the resilience of the more marginalized groups in the villages has weakened. In a study of two villages, Travers et al. (2014) [50] assert that leadership capacity within indigenous communities is crucial to protect communal land from encroachment by outsiders and market forces. They found that weak leadership could not ensure land security for indigenous members, leading to land exclusion by market forces (cf. Hall et al., 2011 [51]). However, in Pukong it was the power relations within and outside of the community that created barriers to tackle the land encroachment although market forces could play some role in the context of cash crop cultivation. While we are supportive of the basic principles of communal land ownership, in the case of Cambodia it is increasingly obvious that CLT is not a genuine process to ensure land ownership of indigenous people, but rather another exclusionary power that opens the way for indiscriminate commons grabbing.

Our findings also indicate that the government's agricultural strategies on permanent farms have made indigenous farmers vulnerable to market price volatility. This has caused income inequality, land concentration, and social differentiation within the indigenous communities. Our 2003 and 2015 
studies describe how corporate ventures in Srae Preah Commune have led to indigenous villages being dispossessed of land and forest resources and reveal how the exclusionary effects of market integration inhibit indigenous residents from participating in certain types of wage work and from becoming entrepreneurs and traders, thus relegating them to a status of semi-proletarians and compromising their livelihood resilience. These results support De Koninck et al.'s (2012) [52] findings from long-term studies in Southeast Asia that the impoverishment of significant numbers of people involved displacement from land and other productive natural resources in the face of rapid wealth generation. This has been brought about by capital-intensive extractive ventures, combined with displaced people's lack of access to other agrarian and non-agrarian livelihood opportunities. Vandergeest \& Rigg (2012) [53] pursue this discussion further and reiterate that where exit options are limited, vulnerability to marginalization and displacement grows as does impoverishment induced by commercialization and resource extraction. We affirm the position of Vandergeest \& Rigg (2012) that where exit options are stymied or of poor quality, the governance and allocation of land and natural resources remain critical for resilient local livelihoods. This is particularly the case in upland areas inhabited by indigenous people who have been marginalized in part due to their ethnicity.

The accumulation of land in the hands of better-off households threatens to result in the dispossession of smallholders potentially to the point of landlessness. While cassava production created opportunities for agricultural labor, very poor households in both communes earned proportionally less from wage work than did most other income groups. Moreover, the very poor households, like the other income groups, earned little or nothing from trading and migrant remittances. This indicates that livelihood opportunities and exit options for the very poor households remain extremely limited under these dramatic changes. Loss of upland farming opportunities and access to forest resources would, no doubt, leave them further displaced and marginalized. As a result, the weakened livelihood sources would make them more vulnerable or less resilient to environmental changes or natural hazards. Our case studies confirm that commons grabbing is a form of "resilience grabbing" whereby livelihood adjustments cannot adequately compensate for the dramatic loss of common pool resources that have sustained previous livelihoods options (cf. Haller 2016 [46]; Marfurt et al. 2016 [54]; Dell' Angelo et al. 2017 [55]). Moreover, this form of "resilience grabbing" involves both livelihoods and culture. As noted by McAndrew (2000) in a study of indigenous villages in neighboring Ratanakiri Province, land takeovers "have not only diminished natural resources necessary for sustaining livelihoods, they have also debilitated cultural and social resources needed to deal with the exigencies of change itself ([56], p. 50)."

\section{Conclusions}

This article has argued that the Cambodian government incoherent laws and policies on ELCs and CLTs undermined indigenous people's access to common land. The ELCs in the two villages did not provide significant benefits to local people in terms of employment opportunities and poverty alleviation as expected in the government's proclaimed goals of long-term investment in agriculture. They in fact further diminished communities' forest resources through logging and forest clearance. Indigenous villagers are being restrained from accessing their common land by the government laws and policies such as the Forestry Law of 2002, which prohibits land clearance inside protected areas. Yet, their common land was encroached upon by corporations, powerful elite, and landless in-migrants. Consequently, indigenous farmers used different strategies to demand compensation for the loss of their common land, including outright resistance and ostensible accommodation.

Further, our study provides evidence that the CLT policy facilitated 'resilience grabbing' by weakening indigenous communities' livelihood sources and thus their abilities to cope with present and future environmental disturbances. The policy did not provide indigenous people with an institutionalized instrument to counteract land grabbing by the ELCs, local elite and in-migrants. Likewise, the ELCs did not provide monetary compensation or jobs to the local communities. Instead, the companies employed Khmer in-migrants who exacerbated communal land grabbing. The loss of 
common resources upon which indigenous livelihoods used to rely severely weakens their adaptive capacity and ecological resilience.

Moreover, the ELC-influenced policy drive for cash crop production in the study commune resulted in further livelihood transitions and land use changes that culminated in income inequality and social differentiation. This cash crop trend pushed the transitions of indigenous people's livelihoods relying on natural resources (in 2003) to livelihoods relying on cash crops (in 2012) to livelihoods struggling to be resilient in the face of price downturns (in 2018). While the crop boom stimulated economic growth, the practice exacerbated the diminishing state of forest and land resources. This process, driven by the state-sponsored market economy, also resulted in economic inequality. While the better-off households substantially improved their income through amassing more land, poor households earned very little or even suffered losses from their cash crop cultivation. This widening income inequality and social differentiation is likely to further reduce economic and social resilience among the indigenous communities.

With limited exit strategies, poor indigenous farmers will continue to be threatened with commons grabbing and ensuing "resilience grabbing" by market forces of land commodification. In the face of external threats (including intrusions by in-migrants) and increasing pressure on access to land and forest resources, there is definitely a need to strengthen transnational social movements and human rights advocacy and implement land titling strategies that benefit the poorest and most vulnerable groups in rural Cambodia. Otherwise indigenous people's land areas will continue to recede and the success of their livelihood transitions will remain precarious at best.

To conclude, this article reveals that land grabbing adversely affects communal solidarity and local governance effectiveness. It also demonstrates how commons grabbing-including land sales within the indigenous communities-undermines livelihood resilience and limits the capacity of indigenous people to deal effectively with policies and strategies implemented by much more powerful forces. The Khmer-dominated Cambodian government continues to operate with a different understanding of law, legality, and conflict resolution, and multinational and domestic corporations (through the acquisition of ELCs) wield tremendous economic and political power to pursue their interests with impunity and at the expense of customary landholders. While this article has tried to determine the various ways in which commons grabbing affects the resilience capacity of indigenous people, there are still knowledge gaps with regard to the role of gendered social relations in responding to and accommodating commons grabbing. This will be an important area of future research.

Author Contributions: Conceptualization, S.H., J.M., A.N.; Methodology, S.H., J.M.; Formal Analysis, S.H., J.M.; Investigation, S.H., J.M.; Data Curation, S.H., J.M.; Writing-Original Draft Preparation: S.H., J.M., A.N.; Writing-Review \& Editing, A.N.; Supervision, A.N.; Funding Acquisition, S.H.

Funding: The authors would like to acknowledge the New Zealand ASEAN Scholar Awards (NZAS) for providing scholarship support to the first author's PhD project. We are grateful for a University of Auckland Research Grant for providing support to the fieldwork logistic arrangement and the travel of the first author.

Acknowledgments: The authors would like to thank all research participants in Srae Preah Commune for their collaboration in this study. We acknowledge the contribution of Dane So to the mobile data survey design and providing support with analysis of the fieldwork data. We are grateful to WCS and DPA of the Keo Seima branch for contributing to the GIS map of the studied villages. We would like to thank the participants of the Annual World Bank Conference on Land and Poverty in Washington, DC, in March 2018, who provided valuable feedback on a conference paper in which preliminary findings from our study were presented.

Conflicts of Interest: The authors declare no conflict of interest.

\section{References}

1. Borras, S.M.; Franco, J.C. Political Dynamics of Land-Grabbing in Southeast Asia: Understanding Europe's Role; Transnational Institute: Amsterdam, The Netherlands, 2011.

2. Kugelman, M.; Levenstein, S.L. (Eds.) The Global Farms Race: Land Grabs, Agricultural Investment, and the Scramble for Food Security; Island Press: Chicago, IL, USA, 2012.

3. Pearce, F. The Land Grabbers: The New Fight over Who Owns the Earth; Beacon Press: Boston, MA, USA, 2012. 
4. Kaag, M.; Zoomers, A. (Eds.) The Global Land Grab: Beyond the Hype; Fernwood Publishing: Winnipeg, MB, Canada; Zed Book: London, UK; 2014.

5. Neef, A.; Singer, J. Development-induced displacement in Asia: Conflicts, risks and resilience. Dev. Pract. 2015, 25, 601-611. [CrossRef]

6. Neef, A.; Touch, S.; Chiengthong, J. The politics and ethics of land concessions in rural Cambodia. J. Agric. Environ. Ethics 2013, 26, 1085-1103. [CrossRef]

7. ADHOC. Land Situation in Cambodia 2013; Cambodian Human Rights and Development Association (ADHOC): Phnom Penh, Cambodia, 2014.

8. Oldenburg, C.; Neef, A. Reversing land grabs or aggravating tenure insecurity? Competing perspectives on economic land concessions and land titling in Cambodia. Law Dev. Rev. 2014, 7, 49-77. [CrossRef]

9. McLinden Nuijen, M.; Prachvuthy, M.; van Westen, G. 'Land Grabbing' in Cambodia: Land Rights in a Post-conflict Setting. In The Global Land Grab: Beyond the Hype; Kaag, M., Zoomers, A., Eds.; Zed Books: London, UK, 2014; pp. 152-169.

10. Neef, A.; Touch, S. Local responses to land grabbing and displacement in rural Cambodia. In Global Implications of Development, Climate Change and Disasters: Responses to Displacement from Asia-Pacific; Price, S., Singer, J., Eds.; Routledge: London, UK; New York, NY, USA, 2016; pp. 124-141.

11. Young, S. Popular resistance in Cambodia: The rationale behind government response. Asian Politics Policy 2016, 8, 593-613.

12. Verkoren, W.; Ngin, C. Organizing against land grabbing in Cambodia: Exploring missing links. Dev. Chang. 2017, 48, 1336-1361. [CrossRef]

13. Lamb, V.; Schoenberger, L.; Middleton, C.; Un, B. Gendered eviction, protest and recovery: A feminist political ecology engagement with land grabbing in rural Cambodia. J. Peasant Stud. 2017, 44, 1-20. [CrossRef]

14. Schoenberger, L. Struggling against excuses: Winning back land in Cambodia. J. Peasant Stud. 2017, 44, 870-890. [CrossRef]

15. Un, K.; So, S. Land rights in Cambodia: How neopatrimonial politics restricts land policy reform. Pac. Aff. 2011, 84, 289-308. [CrossRef]

16. Milne, S. Under the leopard's skin: Land commodification and the dilemmas of Indigenous communal title in upland Cambodia. Asia Pac. Viewpoint 2013, 54, 323-339. [CrossRef]

17. Open Development Cambodia. Registered Indigenous Communal Land. 2018. Available online: https: / / opendevelopmentcambodia.net/dataset/?id=registered-indigenous-communal-land (accessed on 3 August 2018).

18. Beban, A.; So, S.; Un, K. From force to legitimation: Rethinking land grabs in Cambodia. Dev. Chang. 2017, 48, 590-612. [CrossRef]

19. Neef, A. Cambodia: Land grabs and rural dispossession by government design. Rural 21 Int. J. Rural Dev. 2016, 50, 20-22.

20. Open Development Cambodia. Economic Land Concessions (ELCs). 2017. Available online: https:// opendevelopmentcambodia.net/dataset/?id=economiclandconcessions (accessed on 8 May 2018).

21. McAndrew, J.P.; Il, O. Access to natural resources: Case studies of Cambodia hill tribes. In Land and Cultural Survival: The Communal Land Rights of Indigenous Peoples; Jayantha, P., Ed.; Asian Development Bank (ADB): Manila, Philippines, 2009; pp. 93-124.

22. National Institute of Statistics. Cambodia Inter-Censal Population Survey 2013 Final Report; Ministry of Planning: Phnom Penh, Cambodia, 2013.

23. Asian Development Bank. Health and Education Needs of Ethnic Minorities in the Greater Mekong Sub-Region; Cambodia Country Report; Asian Development Bank (ADB): Manila, Philippines, 2000.

24. Backstrom, M.; Ironside, J.; Paterson, G.; Padwe, J.; Baird, I.G. Case Study: Indigenous Traditional Legal Systems and Conflict Resolution in Ratanakiri and Mondulkiri Provinces, Cambodia; United Nations Development Programme (UNDP): Phnom Penh, Cambodia, 2007.

25. National Institute of Statistics. Demographic Census 2008; Ministry of Planning: Phnom Penh, Cambodia, 2009.

26. National Institutes of Statistics. Cambodia Indigenous People Inter-Censal Survey; Unofficial Report; Ministry of Planning: Phnom Penh, Cambodia, 2018.

27. Chheang, V.; Dulioust, J. Rural-Rural Migrations in Cambodia; Policy Paper; Supreme National Economic Council and Agence Francaise de Développement: Phnom Penh, Cambodia, 2012. 
28. Fox, J.; McMahon, D.; Poffenberger, M.; Vogler, J. Land for My Grandchildren: Land Use and Tenure Change in Ratanakiri: 1989-2007; Community Forestry International (CFI) and East West Center Honolulu: Phnom Penh, Cambodia, 2008.

29. Ministry of Agriculture, Forestry and Fisheries. Agriculture Products Statistics 2008. Available online: http:/ / www.maff.gov.kh/ (accessed on 5 December 2017).

30. Ministry of Agriculture, Forestry and Fisheries. Agriculture Products Statistics 2013. Available online: http:/ / www.maff.gov.kh / (accessed on 5 December 2017).

31. Analyzing Development Issues. The Expansion of Mining Activities and Indigenous Peoples' Rights in Mondulkiri Province: Case Studies of Gati Village, Keo Seima District and Pou Rapeth Village, Pechreada District; Cooperation Committee for Cambodia: Phnom Penh, Cambodia, 2010.

32. Wildlife Conservation Society. Village Land Use GIS Map; WCS-Keo Seima District: Mondulkiri, Cambodia, 2018.

33. Open Development Cambodia. Protected Areas. 2016. Available online: https://opendevelopmentcambodia. net/topics/protected-areas/ (accessed on 10 December 2017).

34. Wildlife Conservation Society. REDD+ in Keo Seima Wildlife Sanctuary, Cambodia Monitoring \& Implementation Report 2016-2017; Wildlife Conservation Society: Phnom Penh, Cambodia, 2018.

35. Non-Government Organizations Special Committee Report. 2015. Available online: https:/ /cchrcambodia. org/project_page/land_profile/pdf/28-en.pdf (accessed on 10 December 2017).

36. Brown, S.; Seidel, K.; Sigaty, T. Legal Issues Related to Registration of Lands of Indigenous Communities in Cambodia; German Agency for Technical Cooperation: Phnom Penh, Cambodia, 2005.

37. Royal Government of Cambodia. Sub-Decree on Procedures of Registration of Land of Indigenous Communities; No. 83 ANK, BK; Royal Government of Cambodia: Phnom Penh, Cambodia, 2009.

38. Open Development Cambodia. Communal Land. 2015. Available online: https:// opendevelopmentcambodia.net/topics/communal-land/ (accessed on 5 December 2017).

39. Baird, I.G. 'Indigenous Peoples' and land: Comparing communal land titling and its implications in Cambodia and Laos. Asia Pac. Viewpoint 2013, 54, 269-281. [CrossRef]

40. Ngin, C.; Diepart, J.C. Challenges in Managing State Land in Cambodia: Addressing Competing Interests for Lands inside Protected Areas (PAs); Mekong Land Governance Project: Vientiane, Laos, 2016; Available online: https:/ / orbi.uliege.be/bitstream/2268/198049/1/NGIN-DIEPART_2016_Challenges-ManagingState-Land-Cambodia.pdf (accessed on 7 December 2017).

41. Development and Partner in Action. GIS Map of Srae Ampil Village; Development and Partner in Action: Keo Seima District, Mondulkiri Province, Cambodia, 2018.

42. McAndrew, J.P.; Mam, S.; Hong, K.; Ly, B. Indigenous Adaptation to a Decline in Natural Resources: The Experience of two Phnong Communes in Northeast Cambodia; International Cooperation for Development and Solidarity (CIDSE): Phnom Penh, Cambodia, 2003.

43. Hak, S.; So, D.; Oeur, I.L.; McAndrew, J. Prosperity and poverty: Livelihoods transitions emerging from land use change in two Mondulkiri communes. In Learning for Resilience: Insights from Cambodia's Rural Communities; Diepart, J.C., Ed.; The Leaning Institute: Phnom Penh, Cambodia, 2015; pp. 103-146.

44. Hak, S.; McAndrew, J.; Neef, A. Challenges of governance responses to land use change and poverty among indigenous people in northeast Cambodia. In Proceedings of the Annual World Bank Conference on Land and Poverty "Land Governance in an Interconnected World", Washington, DC, USA, 19-23 March 2018.

45. World Bank. Where Have All the Poor Gone? Cambodia Poverty Assessment 2013; World Bank: Washington, DC, USA, 2013.

46. Haller, T. Managing the commons with floods: The role of institutions and power relations for water governance and food resilience in African floodplains. In Water and Food-Africa in a Global Context; Ostegard, T., Ed.; The Nordic African Institute: Uppsala, Sweden, 2016; pp. 369-397.

47. Scott, J. Everyday forms of peasant resistance. J. Peasant Stud. 1986, 13, 5-35. [CrossRef]

48. Baird, I.G. Resistance and contingent contestations to large-scale land concessions in southern Laos and northeastern Cambodia. Land 2017, 6. [CrossRef]

49. Biddulph, R. Tenure security interventions in Cambodia: Testing Bebbington's approach to development geography. Geogr. Ann. Ser. B Hum. Geogr. 2011, 93, 223-236. [CrossRef] 
50. Travers, H.; Winney, K.; Clements, T.; Evans, T.; Milner-Gulland, E.J. A tale of two villages: An investigation of conservation-driven land tenure reform in a Cambodian Protection Forest. Land Use Policy 2015, 43, 186-196. [CrossRef]

51. Hall, D.; Hirsch, P.; Li, T. Introduction to powers of exclusion. In Powers of Exclusion: Land Dilemmas in Southeast Asia, Challenges of the Agrarian Transition in Southeast Asia; Hall, D., Hirsch, P., Li, T., Eds.; National University of Singapore Press: Singapore, 2011; pp. 1-26.

52. De Koninck, R.; Rigg, J.; Vandergeest, P. A half century of agrarian transformations in Southeast Asia, 1960-2010. In Revisiting Rural Places: Pathways to Poverty and Prosperity in Southeast Asia; Rigg, J., Vandergeest, P., Eds.; University of Hawai'i Press: Honolulu, HI, USA, 2012; pp. 25-37.

53. Vandergeest, P.; Rigg, J. The restudy "problem" and agrarian change: Revisiting rural places in Southeast Asia. In Revisiting Rural Places: Pathways to Poverty and Prosperity in Southeast Asia; Rigg, J., Vandergeest, P., Eds.; University of Hawai'i Press: Honolulu, HI, USA, 2012; pp. 1-24.

54. Marfurt, F.; Käser, F.; Lustenberger, S. Local perceptions and vertical perspectives of a large scale land acquisition project in Northern Sierra Leone. Homo Oecon. 2016, 33, 261-279. [CrossRef]

55. Dell'Angelo, J.; D'Odorico, P.; Rulli, M.C.; Marchand, P. The tragedy of the grabbed commons: Coercion and dispossession in the global land rush. World Dev. 2017, 92, 1-12. [CrossRef]

56. McAndrew, J.P. Indigenous adaptation to a rapidly changing economy: The experience of two Tampuan villages in Northeast Cambodia. Bull. Concerned Asian Sch. 2000, 32, 39-51. [CrossRef]

(C) 2018 by the authors. Licensee MDPI, Basel, Switzerland. This article is an open access article distributed under the terms and conditions of the Creative Commons Attribution (CC BY) license (http://creativecommons.org/licenses/by/4.0/). 